\title{
Assessment of the contamination and genotoxicity of soil irrigated with wastewater
}

\author{
Ying Chen, Chunxia Wang ${ }^{1}$, Zijian Wang \& Shengbiao Huang \\ State Key Laboratory of Environmental Aquatic Chemistry, Research Center for Eco-Environmental Sciences, \\ Chinese Academy of Sciences, Beijing 100085, China. ${ }^{1}$ Corresponding author*
}

Received 19 December 2002. Accepted in revised form 29 July 2003

Key words: contaminated soil, genotoxicity, OCPs, PAHs, wastewater irrigation

\begin{abstract}
Wastewater has been widely used for agricultural irrigation in China and countries in arid and semi-arid areas. Because of poor control of the wastewater quality and long-term application, pollutants accumulation and the relevant ecotoxicological effects may occur, especially for persistent pollutants and permanently bound chemical residues. The pollutants accumulated in soil may transfer through the food chains and cause negative effects on human health. In the present study, a field survey in farmlands that have been irrigated with effluents from a sewage treatment plant and untreated wastewater was carried out. The soil quality was evaluated using a battery of chemical and biological parameters to describe the integrated situations of the polluted sites. Organochlorine pesticides (OCPs) were quantified by GC-ECD and polycyclic aromatic hydrocarbons (PAHs) were analyzed by GC-MS with internal standard. Polyphenol oxidase and catalase activities were examined to investigate the soil functions. Vicia faba micronucleus test was performed to detect the potential genotoxicity of water extracts of the soils. It has been concluded that both PAHs and OCPs have accumulated in the soils irrigated with wastewater. The main origin of PAHs was from the wastewater discharged from a coal plant. The site close to the pollution discharge point was heavily polluted by PAHs. OCPs were mainly residues of historical agriculture application. The MN frequencies and the activity of polyphenol oxidase were positively correlated with PAHs concentrations but have no correlation with OCPs. Therefore, polyphenol oxidase activity and MN frequencies were suggested as the biological indicators of PAHs pollution.
\end{abstract}

\section{Introduction}

Wastewater irrigation has been commonly utilized for agricultural lands in China and countries in arid and semi-arid areas (Barbagallo et al., 2001; Vedry et al. 2001). The agronomic and economic benefits of wastewater irrigation are obvious; however, pollutants could be introduced and accumulated in the soil environment after long-term application because of mismanagement and improper treatment of wastewater. In the past decades, studies on the environmental effects of wastewater irrigation have been dedicated. Accumulation and transfer of heavy metals in the soilplant systems (Al-Nakshabandi et al., 1997; Qadir et

\footnotetext{
* E-mail: cxwang@nsfc.gov.cn
}

al., 2000), the introduction of pathogenic microbes (Shahalam et al., 1998), changes in the basic physical and chemical properties of soil and soil function (Aziz et al., 1999; Hussain and Al-Saati, 1999), as well as influences on plant quality (Aziz et al., 1999; Qadir, 2000) have all been documented. The levels of persistent organic pollutants (POPs) in soils increased by sewage sludge have been widely reported. However, accumulation of POPs and the associated ecological consequences after wastewater irrigation have not been emphasized.

Wastewater treatment plants, especially located in the industrial parks, discharge effluents containing a complex mixture of various organic and inorganic substances. Detailed information of wastewater constituents and their possible biological effects, such as 
toxicity, genotoxicity or estrogenic potency, have been seldom reported. Recently, to evaluate the contamination of environmental samples, toxicity bioassays and chemical analyses have been recommended to be combined (Marinella and Damià, 2003). Our previous work has shown that POPs could not be easily removed from the secondary treatment processes in a sewage treatment plant (STP), in which industrial wastewater was also introduced (Wang et al., 2001).

Micronucleus test (MN) on Vicia faba root tips exposed to the soil water extracts was used to detect the genotoxicity of the contaminated soil. MN assay is sensitive to both mitoclastic and clastogenic agents and is a non-specific genotoxicity biomarker that can reflect different forms of environmental stress (Burgeot et al., 1995). The assay has been successfully used with reliable results for genotoxicity test of environmental pollutants and different chemicals (Kirsch-Volders et al., 2000; Marco et al., 1990). Sometimes, the point mutation test, such as the Ames test and cytogenetic tests on mammalian cells are not able to detect genotoxic effects in soils and falsenegative results have been obtained. Recently, soil genotoxicity has been evaluated using plants, which show higher sensitivity and affordability and allow in situ monitoring of the real conditions of the polluted site studied (Silvano et al., 2002).

In the present study, a preliminary field survey was conducted downstream of the STP. A battery of chemical and biological parameters was adopted to describe the integrated situations of the polluted sites. Chemical analysis of the concentrations and sources of PAHs and OCPs residues, and bioassays including soil enzyme activities and the genotoxicity of soil water extracts were performed.

\section{Materials and methods}

\section{Sample collection and preparation}

Soil samples were collected from six sites in a representative wastewater irrigation farmland downstream of STP in the suburb of Beijing, China (Figure 1). The sampling sites were allocated along the irrigation channels. The water of the channels consists of effluents from the sewage plant and untreated wastewater from a coal plant. There is a dyestuffs factory in the north part of the channels close to site $\mathrm{N} 1$ and $\mathrm{N}_{2}$. At each site, four to five cores of the top soil at the depth of $10 \mathrm{~cm}$ were taken at random and pooled to- gether in the field. All soil samples were sieved (2-mm mesh) and homogenized. After sieving, a sub-sample for organic analysis was freeze-dried and stored at $-20^{\circ} \mathrm{C}$ before chemical analysis, a sub-sample was air-dried for the measurements of soil properties, another sub-sample was stored at $4{ }^{\circ} \mathrm{C}$ for measurements of soil enzyme activities within 2 weeks after sample collection.

\section{Measurements of soil properties and chemical analysis}

The soil $\mathrm{pH}$ was measured in $0.01 \mathrm{M} \mathrm{CaCl}_{2}$ with ratio of 1:1 (soil:solution). Water content of fresh soil $\left(\% \mathrm{H}_{2} \mathrm{O}\right)$ was determined by drying at $105^{\circ} \mathrm{C}$. The content of organic carbon (soil TOC) was determined by a soil TOC analyzer (Apollo 9000, USA).

For the measurement of POPs, 209 of freeze-dried soil sample were Soxhlet extracted for $72 \mathrm{~h}$ with 200 $\mathrm{mL}$ dichloromethane. The solvents were removed by a rotary evaporator (Büchi R-200, Switzerland) and the volume was reduced to ca. $1 \mathrm{~mL}$ in a gentle stream of nitrogen blow (Ultra purity, Tangan, China). The extract was then cleaned using alumina/silica adsorption chromatography capped with anhydrous sodium sulfate to remove water and eluted with $70 \mathrm{~mL}$ mixture of hexane and dichloromethane (7:3, v/v). The volume was reduced to ca. $1 \mathrm{~mL}$ in a gentle stream of nitrogen blow and $10 \mathrm{~mL}$ of hexane was added. It was dried again in nitrogen blow to ca. $0.5 \mathrm{~mL}$ for analysis of OCPs and PAHs.

OCPs were quantified by a gas chromatography equipped with a ${ }^{63} \mathrm{Ni}$ Electron capture detector using Hp-5 column $(30.0 \mathrm{~m}, 0.32 \mathrm{~mm}$ i.d., $0.25 \mu \mathrm{m}$ film thickness). The oven temperature was programmed from $85^{\circ} \mathrm{C}$ (initial time, $2 \mathrm{~min}$ ) to $180^{\circ} \mathrm{C}$ at a rate of $10^{\circ} \mathrm{C} / \mathrm{min}$, and held at $180^{\circ} \mathrm{C}$ for $15 \mathrm{~min}$, then programmed to $280^{\circ} \mathrm{C}$ at a rate of $20^{\circ} \mathrm{C} / \mathrm{min}$ with a final held of $3.5 \mathrm{~min}$. Injections $(1 \mu \mathrm{L})$ were made in the splitless mode and nitrogen at flow rate of 3.4 $\mathrm{mL} / \mathrm{min}$ was used as the carrier gas. Injector and detector temperatures were 280 and $300^{\circ} \mathrm{C}$, respectively. The OCPs standard (Cat No. 47913, Supelco Co.) consists of 17 compounds.

PAHs was identified and quantified by a HewlettPackard 6890 gas chromatography (Hp-5 capillary column, $30 \mathrm{~m} \times 0.25 \mathrm{~nm}$ i.d., and $0.25 \mu \mathrm{m}$ film thickness) equipped with a 5973 mass spectrometer detector. Oven temperature was programmed from $80^{\circ} \mathrm{C}$ (initial time, $2 \mathrm{~min}$ ) to $200^{\circ} \mathrm{C}$ at a rate of $10^{\circ} \mathrm{C} / \mathrm{min}$, then from 200 to $300^{\circ} \mathrm{C}$ at a rate of $3{ }^{\circ} \mathrm{C} / \mathrm{min}$ with a 


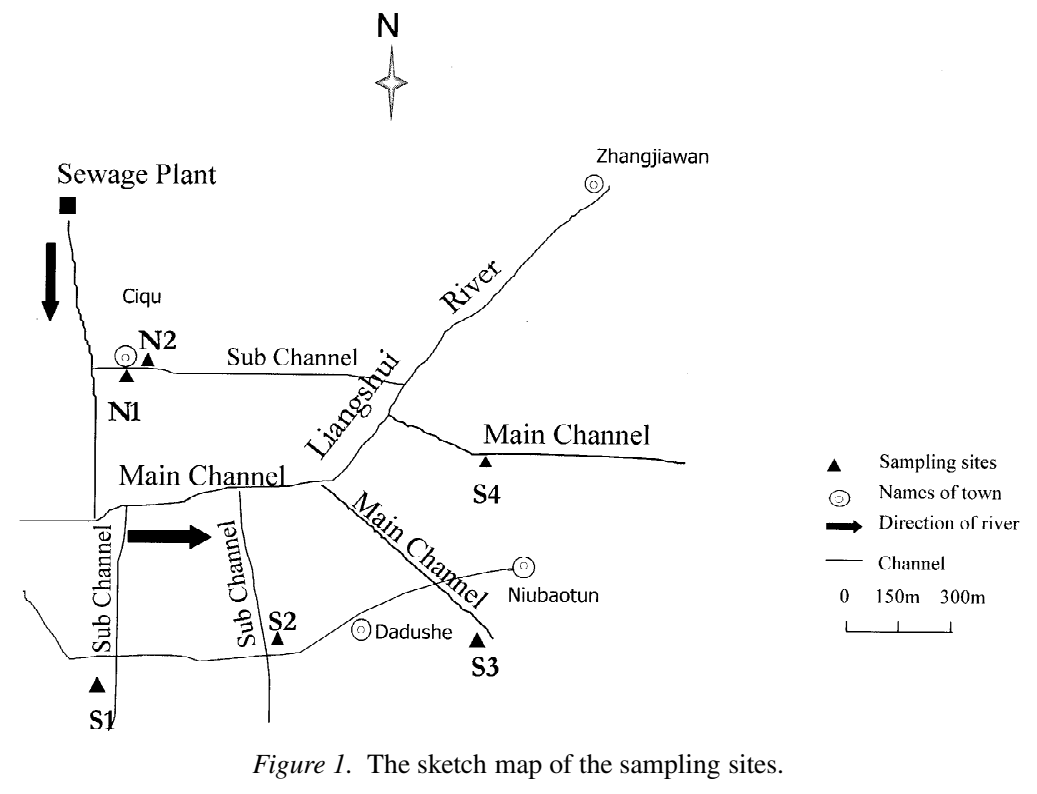

held for $5 \mathrm{~min}$. Injections ( $1 \mu \mathrm{L})$ were made in the splitless mode and helium at a constant flow rate of 1.1 $\mathrm{mL} / \mathrm{min}$ was used as the carrier gas. For identification, selected ion monitoring (SIM) mode was carried out using the molecular ions selective for individual PAHs. Chromatographic data were collected and processed using HP Chemstation software. The PAHs standard (Cat. No.48905-U, Supelco Co.) including 16 priority PAHs was identified using Method-8310 (the U.S. Environmental Protection Agency).

Quantification of each pollutant was performed by individual standard. Phenanthrene- $\mathrm{D}_{10}$ was used as surrogate for calibration of recoveries of PAHs and TMX and PCB209 were used for those of OCPs. The reported values have been corrected against recoveries and on a dry weight basis. The recoveries for PAHs were larger than $80 \%$ and those for OCPs ranged from 60 to $90 \%$.

\section{Analysis of soil enzyme activities}

Polyphenol oxidase was assayed with pyrogallic acid as substrate. The mixture of $1 \mathrm{~g}$ soil and $10 \mathrm{~mL}$ $1 \%$ pyrogallic acid was incubated at $30^{\circ} \mathrm{C}$. A portion of $2.5 \mathrm{~mL} 0.5 \mathrm{M} \mathrm{HCl}$ was added after $1 \mathrm{~h}$ incubation and purpurigallin was extracted by ether. It was then measured by a spectrophotometer (UNICO, UV2000) at $430 \mathrm{~nm}$ and enzymatic activity was calculated according to Zhou (1987).

Catalase was assayed with $\mathrm{H}_{2} \mathrm{O}_{2}$ as substrate. The mixture of $2 \mathrm{~g}$ soil, $40 \mathrm{~mL}$ distilled water and $5 \mathrm{~mL}$
$0.3 \% \mathrm{H}_{2} \mathrm{O}_{2}$ was shaken for $20 \mathrm{~min}$ at $25^{\circ} \mathrm{C}$. After filtration, $5 \mathrm{~mL} 3 \mathrm{M} \mathrm{H}_{2} \mathrm{SO}_{4}$ was added to $10 \mathrm{~mL}$ extract and the remaining $\mathrm{H}_{2} \mathrm{O}_{2}$ was determined by $0.1 M \mathrm{KMnO}_{4}$ solution. The enzymatic activity was calculated according to Zhou (1987).

All measurements for enzyme activities were performed in triplicates and the results were reported in averages and on oven-dried soil basis $\left(105^{\circ} \mathrm{C}\right)$.

\section{Genotoxicity test}

Soil water extract was prepared by shaking a portion of soil with distilled water (dried soil:water, 1:2). The suspension was shaken for $24 \mathrm{~h}$ at $23 \pm 2{ }^{\circ} \mathrm{C}$ and then centrifuged for $15 \mathrm{~min}$ at $13000 \times \mathrm{g}$. The supernatant was stored at $4{ }^{\circ} \mathrm{C}$ in the dark for $\mathrm{MN}$ test within 2 days (DECHEMA 1995). Vicia faba beans (provided by Huazhong University) were grown in distilled water at $23 \pm 2{ }^{\circ} \mathrm{C}$ for 3 days. Then the germinated beans were exposed to soil water extract or negative control (double distilled water) for $5.5 \mathrm{~h}$ followed by a $24-\mathrm{h}$ recovery period. The roots were merged in a mixture of acetone and ethanol (3:1) for $22 \mathrm{~h}$ and stored in $70 \%$ ethanol. Root tips were hydrolyzed with $5 M$ $\mathrm{HCl}$ at $28^{\circ} \mathrm{C}$ for $25 \mathrm{~min}$ and then squashed and Feulgen stained for $3.5 \mathrm{~h}$. Three slides from six beans were prepared and 1000 cells per slide were scored for each site. The genotoxicity potencies of the individual samples were determined based on the $\mathrm{MN}$ frequencies per 1000 cells (MN\%o) and the pollution index (PI) value. The identification of PI has been used 
Table 1. Basic properties of the soil samples

\begin{tabular}{llrl}
\hline Station & $\begin{array}{l}\mathrm{pH} \\
\left(\mathrm{CaCl}_{2}\right)\end{array}$ & $\begin{array}{l}\mathrm{H}_{2} \mathrm{O} \\
(\%)\end{array}$ & $\begin{array}{l}\text { TOC } \\
(\%)\end{array}$ \\
\hline $\mathrm{N} 1$ & 4.9 & 7.5 & 1.11 \\
$\mathrm{~N} 2$ & 6.0 & 7.5 & 0.95 \\
$\mathrm{~S} 1$ & 5.3 & 12.9 & 1.51 \\
$\mathrm{~S} 2$ & 5.1 & 10.0 & 0.91 \\
$\mathrm{~S} 3$ & 5.1 & 8.6 & 1.20 \\
$\mathrm{~S} 4$ & 4.9 & 14.6 & 1.62 \\
\hline
\end{tabular}

for the classification of the polluted water to avoid the influence of the background in individual tests. The MN\%o observed after exposure to the water extract were analyzed statistically, and significant differences (at 0.05 or 0.01 level) between the negative control and a series of treated groups were determined by the Student's test (Jin and Chen, 1998). The MN\%o and PI were calculated as following:

$$
\begin{gathered}
\text { MNG }=\frac{\text { Number of cells containing MN }}{\text { Total number of cells counted }} \times 1000 \% 0 \\
\mathrm{PI}=\frac{\mathrm{MN} \% 0 \text { of the sample }}{\mathrm{MN} \% \text { of the negative control }}
\end{gathered}
$$

\section{Results and discussions}

The general soil properties including water content, $\mathrm{pH}$ and TOC are listed in Table 1. It could be seen that TOC of the six soil samples varied from $0.91 \%$ $(\mathrm{S} 2)$ to $1.62 \%(\mathrm{~S} 4)$ and $\mathrm{pH}$ from $4.9(\mathrm{~N} 1)$ to $6.0(\mathrm{~N} 2)$, respectively.

\section{Concentrations of PAHs}

The concentrations of PAHs in soils are given in Table 2. Among all the sampling sites, the levels of total PAHs for the six samples varied from $41.8 \mathrm{ng} / \mathrm{g}$ in $\mathrm{S} 2$ to $916.0 \mathrm{ng} / \mathrm{g}$ in N1. There were $15 \mathrm{PAHs}$ identified in N1. Fluoranthene, pyrene, chrysene, benz $[a]$ anthracene and benz $[b]$ fluoranthene were the dominant species in all the samples, while benzo $[a, h]$ anthracene $(8.0 \mathrm{ng} / \mathrm{g})$ and benz $[a]$ pyrene $(58.8 \mathrm{ng} / \mathrm{g})$ were only found in N1. Generally, concentrations of PAHs in soil along upstream of the channels were higher than that from downstream; however, there were exceptions. It suggested, therefore the source of PAHs were

\begin{tabular}{|c|c|c|c|c|c|c|}
\hline \multirow[t]{2}{*}{ Compounds } & \multicolumn{6}{|c|}{ PAHs concentrations (ng/g dw ${ }^{a}$ ) } \\
\hline & $\mathrm{N} 1$ & N2 & $\mathrm{S} 1$ & S2 & S3 & $\mathrm{S} 4$ \\
\hline Naphthalene & 11.8 & 49.5 & nd & nd & nd & 29.3 \\
\hline Acenaphthylene & 20.3 & 5.3 & nd & 2.0 & nd & nd \\
\hline Acenaphthene & 9.0 & 5.5 & nd & 1.3 & 3.3 & 3.0 \\
\hline Fluorene & 16.3 & 23.0 & 13.3 & 2.8 & 9.5 & 12.8 \\
\hline Phenanthrene & 73.0 & 83.3 & 81.8 & 9.0 & 43.5 & 62.8 \\
\hline Anthracene & 15.0 & nd & nd & nd & nd & nd \\
\hline Fluoranthene & 99.3 & 45.5 & 51.3 & 9.5 & 37.5 & 37.5 \\
\hline Pyrene & 70.3 & 31.0 & 31.8 & 7.5 & 36.0 & 25.5 \\
\hline Chrysene & 53.8 & 16.5 & 12.5 & 1.3 & 22.5 & 12.5 \\
\hline Benz $[a]$ anthracene & 101.0 & 33.5 & 32.5 & 3.5 & 41.8 & 29.8 \\
\hline Benz $[b]$ fluoranthene & 120.3 & 27.5 & 22.8 & 5.0 & 40.0 & 24.3 \\
\hline Benz $[k]$ fluoranthene & 148.8 & 27.8 & 0.9 & nd & 44.0 & 23.3 \\
\hline $\operatorname{Benz}[a]$ pyrene & 58.8 & nd & nd & nd & nd & nd \\
\hline Indeno $[1,2,3-c d]$ pyrene & 110.8 & 2.0 & nd & nd & 28.8 & 1.8 \\
\hline Dibenzo $[a, h]$ anthracene & 8.0 & nd & nd & nd & nd & nd \\
\hline$\Sigma \mathrm{PAHs}$ & 916.0 & 350.3 & 246.6 & 41.8 & 306.8 & 262.3 \\
\hline
\end{tabular}

Table 2. PAHs concentrations of the soil samples

${ }^{\text {a}}$ Dry weight (soil).

mainly from water, instead of atmospheric deposition. It should be noted from Table 1. that the soil TOC varied slightly with sampling sites, indicating PAHs pollution was not due to or accompanied with accumulation of soil organic matters. The levels of PAHs in the two sites close to each other, N1 and N2, were different and supported the influence of the agriculture activities in the region.

The origin of PAHs has often been discerned by studying the distribution of PAHs with the same molecular weight and similar structure (Sanders et al., 2002). The ratios of phenanthrene/anthracene (Phe/Ant) within the three-ring PAHs and fluoranthene/pyrene (Flu/Pyr) within the four-ring PAHs were used to form the molecular indices. Generally, Phe/Ant ratio $<10$ and Flu/Pyr ratio $>1$ indicate that PAHs originate from pyrogenic source while a Phe/Ant $>15$ and Flu/Pyr $<1$ indicate petrogenic origins of PAHs (Baumard et al., 1998). The ratios of Phe/Ant and Flu/Pyr are listed in Table 3. The Flu/Pyr ratios in all samples ranged from 1.0 to 1.6 and Phe/Ant ratio at $\mathrm{N} 1$ was 4.9 , which was less than 10. There was no detectable anthracene (Ant) in other sites. Accordingly the origins of PAHs in the soils could be from pyrogenic source. In addition, the ratios of two- to three-ringed PAHs to more than four-ringed PAHs ranged from 0.2 to 0.9 . Generally the pyrogenic sources discharge mainly PAHs with more than four 
Table 3. The values of PAHs origin indexes in each sampling sites

\begin{tabular}{lllll}
\hline Station & $\begin{array}{l}\text { Flu/Pyr } \\
\text { index }\end{array}$ & $\begin{array}{l}\text { Phe/Ant } \\
\text { index }\end{array}$ & $\begin{array}{l}\text { Ratio of } \\
2-3 />4- \\
\text { ringed PAHs }\end{array}$ & $\begin{array}{l}\text { Dominant } \\
\text { source } \\
\text { of origin }\end{array}$ \\
\hline N1 & 1.4 & 4.9 & 0.2 & Pyro \\
N2 & 1.5 & - & 0.9 & Pyro \\
S1 & 1.6 & - & 0.6 & Pyro \\
S2 & 1.3 & - & 0.6 & Pyro \\
S3 & 1.0 & - & 0.2 & Pyro \\
S4 & 1.5 & - & 0.7 & Pyro \\
\hline
\end{tabular}

Table 4. OCPs concentrations of the soil samples

\begin{tabular}{lllllll}
\hline \multirow{2}{*}{ OCPs } & \multicolumn{6}{c}{ OCPs concentrations (ng/g dw) } \\
\cline { 2 - 7 } & $\mathrm{N} 1$ & $\mathrm{~N} 2$ & $\mathrm{~S} 1$ & $\mathrm{~S} 2$ & $\mathrm{~S} 3$ & $\mathrm{~S} 4$ \\
\hline$\alpha-\mathrm{HCH}$ & nd & nd & 0.97 & $1.19 \mathrm{E}+2^{\mathrm{a}}$ & 0.39 & 0.23 \\
$\beta$-HCH & 0.89 & nd & 8.53 & $2.19 \mathrm{E}+2$ & 2.83 & 1.44 \\
$\gamma$-HCH & 0.24 & nd & 2.14 & $2.82 \mathrm{E}+2$ & 0.72 & 0.76 \\
$\delta$-HCH & 0.23 & 1.86 & 3.45 & $4.68 \mathrm{E}+3$ & 0.73 & 0.65 \\
Aldrin & nd & 1.96 & 5.92 & $1.36 \mathrm{E}+1$ & 4.72 & 1.56 \\
Endosulfan I & 0.18 & 0.55 & 0.12 & 0.95 & nd & 0.07 \\
$p, p^{\prime}-\mathrm{DDE}$ & 0.90 & 1.27 & 4.72 & 9.88 & $1.11 \mathrm{E}+1$ & 4.29 \\
$p, \mathrm{p}^{\prime}-\mathrm{DDD}$ & 0.42 & 0.47 & 3.39 & 2.34 & 1.41 & 0.38 \\
$p, p^{\prime}-\mathrm{DDT}$ & 3.83 & 0.98 & 8.35 & $1.90 \mathrm{E}+1$ & 3.67 & 1.41 \\
$\Sigma$ OCPs & 6.69 & 7.09 & 37.60 & $5.34 \mathrm{E}+3$ & 25.60 & 10.80 \\
\hline
\end{tabular}

$\mathrm{a} 1.19 \mathrm{E}+2=119$

rings as a result of incomplete combustion. Therefore, the pollutant sources in the soils should originate from the incomplete combustion of organic material and this was substantiated by the discharges from the coke plant, which was mixed into the irrigation water.

\section{Concentrations of $\mathrm{OCPs}$}

The total OCPs concentrations in soil samples varied greatly from $6.69 \mathrm{ng} / \mathrm{g}$ in N1 to $5.34 \times 10^{3} \mathrm{ng} / \mathrm{g}$ in S2 (Table 4). The results for individual OCPs percentages are demonstrated in Figure 2.

Past and present pollutant emission sources of DDT can be distinguished from the ratio of parent/metabolite and isomeric compositions. The ratios of DDT/DDE and percentage of individual isomer to sum of HCHs for soil samples are tabulated in Table 5.

DDT can be transformed microbially to DDE and DDD. Generally the ratio of parent/metabolite decreases with time (Dimond and Owen, 1996). A small
Table 5. The ratio of DDT/DDE and percentages of the HCHs isomers within a substance group in the sampling sites

\begin{tabular}{|c|c|c|c|c|c|}
\hline \multirow[t]{2}{*}{ Station } & \multirow[t]{2}{*}{ DDT/DDE } & \multicolumn{4}{|c|}{$\begin{array}{l}\text { Percentages of isomers to the total } \mathrm{HCHs} \\
\qquad(\%)\end{array}$} \\
\hline & & $\alpha-\mathrm{HCH}$ & $\beta$-HCH & $\gamma-\mathrm{HCH}$ & $\delta$-HCH \\
\hline N1 & 4.3 & 0.0 & 65.5 & 17.7 & 16.9 \\
\hline $\mathrm{N} 2$ & 0.8 & 0.0 & 0.0 & 0.0 & 100.0 \\
\hline S1 & 1.8 & 6.4 & 56.5 & 14.2 & 22.9 \\
\hline S2 & 1.9 & 2.3 & 4.1 & 5.3 & 88.3 \\
\hline S3 & 0.3 & 8.3 & 60.6 & 15.5 & 15.6 \\
\hline S4 & 0.3 & 7.6 & 46.9 & 24.6 & 21.0 \\
\hline
\end{tabular}

Table 6. Genotoxicity parameters of the soil samples obtained from the MN test

\begin{tabular}{lll}
\hline Station & MN\%o \pm SD & PI \\
\hline N1 & $23.7 \pm 4.51^{*}$ & 3.9 \\
$\mathrm{~N} 2$ & $17.7 \pm 1.15$ & 3.0 \\
S1 & $19.7 \pm 4.04^{*}$ & 3.3 \\
S2 & $18.7 \pm 1.15$ & 3.1 \\
S3 & $21.0 \pm 4.4^{*}$ & 3.5 \\
S4 & $18.7 \pm 0.58$ & 3.1 \\
Negative control & $6.0 \pm 1.00$ & - \\
\hline$*<0.05$, others $P<0.01$ (with control: \\
$t$-test).
\end{tabular}

value of the DDT/DDE ratio indicates aged DDT except that some soils were observed high proportion of DDT because of their poor metabolic capability. Previous studies reported that after long-term metabolism the ratios were usually between 0.5 and 2 and occasionally > 5 (Aigner, 1998; Dimond and Owen, 1996). In our study, the ratios were between 0.3 and 1.9 and classified as aged soil, excepting for N1 whose DDE/DDD ratio was 4.3.

Among HCHs, $\gamma$-HCH can be completely decomposed or biotransformed into other isomers in agricultural upper soils within 3 years with an average half-life of approximately 2 months (Turnbull, 1997). If the $\alpha-\mathrm{HCH}$ prevails, new inputs source may be present in the area. Otherwise, concentrations of more stable $\alpha-\mathrm{HCH}$ and $\delta$-HCH should be relatively higher comparing to $\beta$ - $\mathrm{HCH}$ due to isomerization process (Manz et al., 2001). In our study, higher portion of $\delta$ - $\mathrm{HCH}$ was observed at $\mathrm{N} 2$ and $\mathrm{S} 2$ and $\beta$ - $\mathrm{HCH}$ prevailed in the other sites. Therefore the observed $\mathrm{HCHs}$ residues should be historically applied pesticides in this agricultural area. Higher concentration of HCHs 


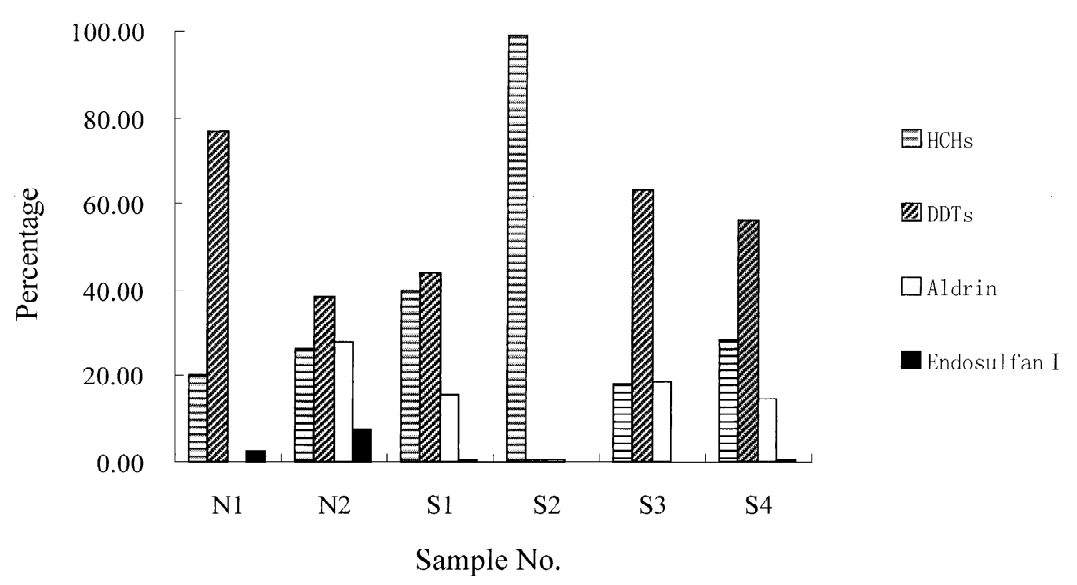

Figure 2. Components of the OCPs found in the soils.

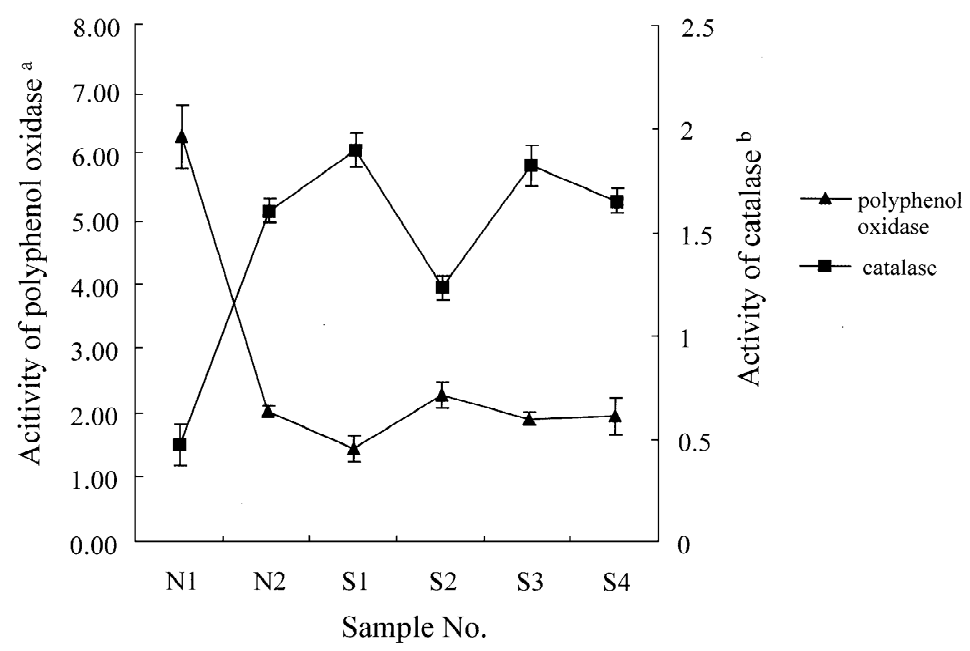

${ }^{a} \mathrm{mg}$ purpurigallin $\mathrm{g}^{-1} \mathrm{~h}^{-1}$

${ }^{\mathrm{b}} 0.1 N(\mathrm{KMnO} 4) \mathrm{g}^{-1}$ (20min)

Figure 3. Polyphenol oxidase and catalase activities of the soils.

found in S2 may suggest a historical point source of $\mathrm{HCHs}$ in nearby area.

\section{Enzyme activities}

Soil enzyme activities are significant indicators of soil ability to degrade organic matters (Dick, 1997). In present work, polyphenol oxidase and catalase activities were measured as indicators of soil integrity and plotted with sampling sites in Figure 3. It could be seen from these figures that activities of polyphenol oxidase and catalase were negatively correlated. There were correlations between enzymatic activity and concentrations of total PAHs for the sampling sites. The correlation coefficients $(R)$ were 0.90 for polyphenol oxidase as demonstrated in Figure 4 and -0.73 for catalase, respectively. The highest enzymatic activity of phenol oxidase was observed at N1, corresponding to the highest concentration of aromatic compounds in soil. Phenols were major components in wastewater from the coking plant and they were degradation products of aromatic compounds (Xia, 2002). The soil activity of phenol oxidases may be induced when phenols or aromatic compounds are introduced into soil (Zhou, 1987).

There was no correlation between polyphenol oxidase and catalase activities and total OCPs. Pesticides in soil may cause toxic effects to the soil biota and reduced the enzymatic activity. However, even the activ- 


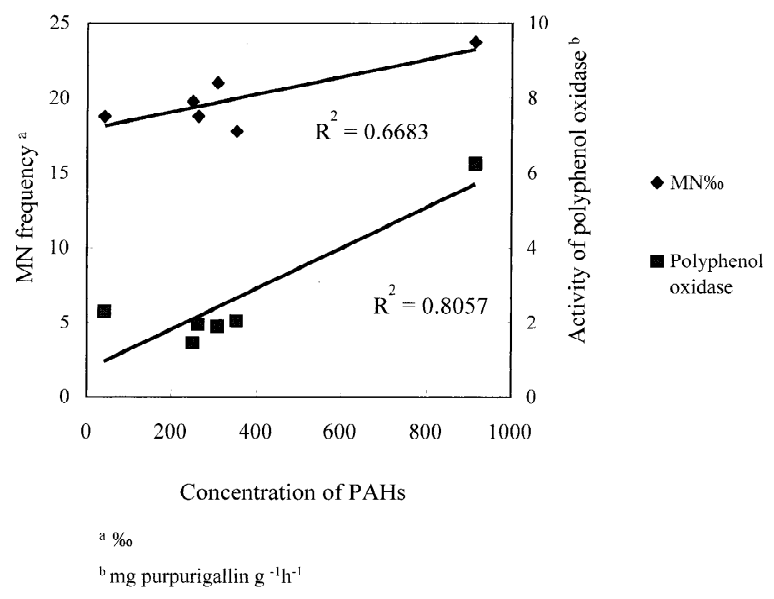

Figure 4. Correlations of MN\%o and polyphenol oxidase activity with the total PAHs.

ities of soil enzymes may be inhibited or enhanced, they will be recovered soon ( $\mathrm{Li}, 1996)$.

\section{Genotoxicity}

The genotoxicity of the six soil samples is given in Table 6 in forms of MN\%o and PI value. It has been found that all samples had significant genotoxicity to the Vicia faba with MN\%o from 23.7 in N1 to 17.7 in N2. Generally, pollution levels are divided into four grades based on PI values: 0-1.5, no pollution; $1.5-2$, light pollution; 2-3.5, medium pollution; and, above 3.5, heavy pollution (Jin and Chen, 1998). In concordance with the concentrations of PAHs and enzyme activities, N1 with the highest PI value (3.9) reaches heavy pollution level.

The correlation coefficient $(R)$ of total PAHs and MN\%o was 0.81 as demonstrated in Figure 4, and no correlation was found between MN\%o and total OCPs. PAHs are known to be pro-mutagenic pollutants, Vicia faba MN test was also used by Sandra et al. (1998) to examine the mutagenicity of sediments containing PAHs, in which seeds were directly exposed to the synthetic soil mixture. All the samples showed significantly positive results with the similar PAHs range of 100-1000 ng/g which was in accordance with present study.

However, in addition to the studied chemicals, there exist many other substances in wastewater and the contaminated soil which should contribute to toxicities. Further exploration is needed to diagnose other mutagenic pollutants in the soil water extract using other indicators.

\section{Conclusions}

Based on the results obtained, it could be concluded that both PAHs and OCPs have accumulated in the soils irrigated with wastewater. The main source of PAHs was from wastewater discharged from coal plant. The site N1 close to the pollution discharge point has the highest total PAHs concentration. OCPs were mainly from historically residue of agricultural application. S2 was polluted by great amount of HCHs, which was obviously different from other sites. The genotoxicity of the soil water extract were correlated well with PAHs concentration but had no correlation with OCPs. All the soil samples from the area have potential mutagenic effects. N1 was heavily polluted by PAHs with highest polyphenol oxidase activity and lowest catalase activity and greatest genotoxicity. The soil polyphenol oxidase activity and micronucleus frequencies were suggested as the biological indicators of the pollution caused by PAHs.

\section{Acknowledgements}

This work was supported by National Natural Science Foundation of China (No. 40171050 and No. 20237010).

\section{References}

Aigner E J, Leone A D and Falconer R L 1998 Concentrations and enantiomeric ratios of organochlorine pesticides in soils from the U.S. Corn Belt. Environ. Sci. Technol. 32, 1162-1168.

Al-Nakshabandi G A, Saqqar M M, Shatanawi M R, Fayyad M and Al-Horani H 1997 Some environmental problems associated with the use of treated wastewater for irrigation in Jordan. Agric. Water Manage. 34, 81-94.

Aziz O, Inam A and Samiullah 1999 Utilization of petrochemical industry waste water for agriculture. Water Air Soil Pollut. 115, 321-335.

Barbagallo S, Cirelli G L and Indelicato S 2001 Wastewater reuse in Italy. Wastewater Reclamation, recycling and reuse. Water Sci. Technol. 43, 43-50.

Baumard P, Budzinski H, Michon Q, Garrigues P, Burgeot T and Bellocq J 1998 Origin and bioavailability of PAHs in the Mediterranean Sea from mussel and sediment. Estuar. Coast. Shelf Sci. 47, 77-90.

Burgeot T, His E and Galgani F, 1995 The micronucleus assay in Crassostrea gigas for the detection of seawater genotoxicity. Mutat. Res. 342, 125-140.

DECHEMA 1995 Bioassays for soils, 4th Report of the Interdisciplinary DECHEMA Committee, Environmental Biotechnology-Soil, Ad hoc Committee, Methods for Toxicological/Ecotoxicological Assessment of Soil. DECHEMA e.V., Frankfurt am Main, Germany. 
Dick R P 1997 Soil enzyme activities as integrative indicators of soil health. In: Biological Indicators of Soil Health. Eds. Pankhurst C, Doube B M and Gupta V V S R. pp. 121-156. CAB International, Wallingford, New York.

Dimond J B and Owen R B 1996 Long-term residue of DDT compounds in forest soils in Maine. Environ. Pollut. 92, 227-230.

Hussain G and Al-Saati A J 1999 Wastewater quality and its reuse in agriculture in Saudi Arabia. Desalination. 123, 241-251.

Jin B and Chen G R 1998 Genotoxicity and Environmental Examination. Middle-China Normal University Press, Wuhan, China. pp. 275-280.

Kirsch-Volders M, Sofuni T, Aaderma M, Albertini S, Eastmond D, Fenech M, Ishidate M, Lorge E, Norppa H, Surallés J, Von der Hude W and Wakata A 2000 Report from the vitro micronucleus assay working group. Environ. Mol. Mutagen. 35, 167-172.

Li F D 1996 The Soil Microbiology. Chinese Agriculture Press, Beijing, China.

Manz M, Wenzel K D, Dietze U and Schüürmann G 2001 Persistent organic pollutants in agricultural soils of central Germany. Sci. Total Environ. 277, 187-198.

Marco A D, Boccardi P, Simone C D, Raglione M, Testa A and Strinca S 1990 Induction of micronuclei in Vicia faba root tips treated in different soils with the herbicide alachlor. Mutat Res. 241, 1-6.

Marinella F and Damià B 2003 Toxicity testing of wastewater and sewage sludge by biosensors, bioassays and chemical analysis. TrAC 22, 299-310.

Qadir M, Ghafoor A and Murtaza G 2000 Cadmium concentration in vegetables grown on urban soils irrigated with untreated municipal sewage. Environ. Dev. Sustainability. 2, 11-19.
Sandra M, Daniela C, Fabio P, Angiolina G, Eleonora C and Marco R 1998 Mutagenicity (micronucleus test in Vicia faba root tips), polycyclic aromatic hydrocarbons and heavy metal content of sediments collected in Tiber river and its tributaries within the urban area of Rome. Mutat Res. 77-84.

Sanders M, Sivertsen S and Scott G 2002 Origin and distribution of polycyclic aromatic hydrocarbons in surficial sediments from the Savannah River. Arch. Environ. Contam. Toxicol. 43, 438-448.

Shahalam A, Zahra B M A and Jaradat A 1998 Wastewater irrigation effect on soil, crop and environment: A pilot scale study at Irbid, Jordan. Water Air Soil Pollut. 106, 425-445.

Silvano M, Donatella F, Ilaria Z, Adriana A, Claudia Z, Sergio R, Umberto G and Giuseppe N 2002 Soil contamination detected using bacterial and plant mutagenicity tests and chemical analyses. Environ. Res. 88, 64-69.

Turnbull A 1997 Chlorinated pesticides. In Chlorinated Organic Micropollutants. Eds. Hester R E and Harrison R M. pp. 113135. Letch-worth, UK: the Royal Society of Chemistry Issues in Environmental Science and Technology Series.

Vedry B, Gousailles M, Affholder M, Lefaux A and Bontoux J 2001 From sewage water treatment to wastewater reuse. One century of Paris sewage farms history. Water Sci. Technol. 43, 101-107.

Wang Y, Ma M, Wang C X, Mo Z and Wang Z J 2001 Monitoring priority pollutants in a sewage treatment process by dichloromethane extraction and triolein-semipermeable membrane device (SPMD). Chemosphere. 43, 339-346.

Xia B C 2002 Biodegradation of Environmental Pollutants. The Chemical Industry Publisher, Beijing, China. 234 pp.

Zhou L K 1987 The Science of Soil Enzymes. The Science Press, Beijing, China. pp. 267-270. 